\title{
A rede de pesquisadores reunidos por Silvio Macedo sob o Lab QUAPÁ e os estudos de sistemas de espaços livres e formas urbanas no Brasil
}

\author{
The research network gathered by Professor Silvio Macedo under the QUAPÁ \\ Lab and the studies of open space systems and urban forms in Brazil
}

Eugenio Fernandes Queiroga[a] $[$, , Francine Gramacho Sakata[a] (1)

[a] Universidade de São Paulo (USP), Faculdade de Arquitetura e Urbanismo, São Paulo, SP, Brasil

Como citar: Queiroga, E. F., \& Sakata, F. G. (2020). A rede de pesquisadores reunidos por Silvio Macedo sob o Lab QUAPÁ e os estudos de sistemas de espaços livres e formas urbanas no Brasil. urbe. Revista Brasileira de Gestão Urbana, 12, e20190264. https://doi.org/10.1590/2175-3369.012.e20190264

\section{Resumo}

No Brasil, Miranda Magnoli, nos anos 1970, estruturou o Grupo de Disciplinas Paisagem e Ambiente da Faculdade de Arquitetura e Urbanismo da Universidade de São Paulo e seu conceito de espaços livres; com isso, abriu frente de estudos sobre relações entre espaços livres e formas urbanas. Silvio Macedo, ao longo de cinco décadas, vem reforçando a atenção às formas urbanas e sua articulação com os espaços livres. Passa-se a tomar os espaços livres como sistema e infraestrutura urbana. Macedo e equipe estruturam rede de pesquisadores em universidades de todo o país, difundindo esses conceitos e realizando novas pesquisas. A abordagem tem similitudes com outros autores, mas também busca por novos caminhos que deem conta do processo particular do expressivo crescimento de cidades brasileiras, onde fatores conjunturais são considerados ao lado dos estruturais. 0 artigo faz um relato da trajetória desse grupo, dos principais conceitos e métodos com que trabalha e de resultados gerais de 13 anos de pesquisa em rede, com ênfase no papel articulador do Prof. Silvio Macedo. Resultados apontam para a necessidade de novas estratégias de planejamento no país, que busquem articular a ação dos agentes que produzem os espaços livres e edificados, constitutivos das formas urbanas.

Palavras-chave: Sistemas de espaços livres. Forma urbana. Silvio Macedo. Lab QUAPÁ. Faculdade de Arquitetura e Urbanismo da Universidade de São Paulo.

\section{Abstract}

In the 1970s, the Brazilian Miranda Magnoli structures the Group of Disciplines Landscape and Environment of the Faculty of Architecture and Urbanism of the University of São Paulo and the concept of open spaces. Thus, it starts the study of opens spaces and urban forms. Silvio Macedo, for five decades, emphasizes the articulation between the urban forms and open spaces. In this way, it takes the open spaces as a system and also as an urban infrastructure. Macedo and team structure a network of researchers in universities across the country, spreading these concepts and making new researches. The approach has similarities with other author, but it is also a research for a new way to understand the particular process of strong growth of many Brazilian cities, where the circumstantial factors are considered alongside structural ones. This work gives an

EFQ é professor associado, e-mail: queiroga@usp.br

FGS é professora, doutora, e-mail: francinesakata@gmail.com 
account of the trajectory of this group, the main concepts and methods which it works and the general results of thirteen network research, with emphasis on the central and articulating role of Prof. Silvio Macedo. Some results indicate the need for new planning strategies that seek to articulate the agents that produce open spaces and built spaces constitutive of Brazilian urban forms.

Keywords: Open space systems. Urban form. Silvio Macedo. Lab QUAPÁ. Faculty of Architecture and Urbanism of the University of São Paulo.

\section{Introdução}

A pesquisa e o ensino de Morfologia Urbana assumem diferentes linhas conforme suas próprias histórias, e, no Brasil, a rede de pesquisadores integrados a partir de 2006, sob a liderança do Prof. Silvio Macedo, do Grupo de Disciplinas Paisagem e Ambiente, do Departamento de Projeto da Faculdade de Arquitetura e Urbanismo da Universidade de São Paulo (FAUUSP), constituiu importante linha de investigação correlacionando sistemas de espaços livres (SEL) e formas urbanas de cidades brasileiras. Os trabalhos são conduzidos de maneira descentralizada em cada ponto da Rede Nacional de Pesquisa QUAPÁ-SEL, mas são pautados por conceitos e métodos comuns, compartilhados, principalmente, a partir de Oficinas de Pesquisa e Colóquios da Rede QUAPÁ-SEL, os quais, por sua vez, geram textos e colaborações de natureza diversa.

Este artigo pretende apresentar a importância e a relevância dos 13 anos de trabalho dessa rede, destacando seu coordenador, o Prof. Silvio Macedo, cuja liderança é comprovada pelas dezenas de orientações de ICs, TFGs, mestrados e doutorados, além de artigos e livros publicados.

Pesquisadores como Vera Tângari, da Universidade Federal do Rio de Janeiro (UFRJ), Staël Costa, da Universidade Federal de Minas Gerais (UFMG), Eneida Mendonça, da Universidade Federal do Espírito Santo (UFES), e seus respectivos laboratórios desenvolvem trabalhos próprios com conceitos e métodos em comum. 0 conceito de espaços livres, concebido pela Profa. Miranda Magnoli na FAUUSP nos anos 1970/80, foi o ponto de partida dos membros da rede. 0 estudo das formas urbanas se dá a partir da leitura dos "vazios", ou os espaços livres, em relação aos "cheios", representados pela massa edificada. Silvio Macedo, ao longo dos anos, foi reforçando a atenção às formas e à articulação dos espaços livres, à relação com o relevo, à configuração das quadras, à existência de recuos, à arborização na via ou intralote, ao papel da legislação, entre outros parâmetros de leitura.

A incorporação do conceito de espaços livres como sistema vem, na sequência, como nova premissa. E trata-se de um sistema não apenas por conta de praças, parques e largos, mas, sobretudo, por conta das vias que, estas sim, conectam as partes. O SEL é então tomado como uma infraestrutura urbana, assim como redes de energia ou de abastecimento, fundamental para o funcionamento das cidades.

O escopo do estudo da forma urbana extrapola o entendimento do seu valor estético ou figurativo, permitindo a leitura da transformação da cidade, que se dá de maneira contínua, ora de modo mais intenso, ora mais discreto. Os processos de transformação contemporâneos no Brasil mais evidentes são aqueles que ocorrem pela expansão da mancha urbana, tanto por loteamentos fechados e condomínios para as classes de alta, média e baixa renda, inclusive os empreendimentos vinculados ao Programa Minha Casa Minha Vida (PMCMV), quanto por loteamentos destinados à logística e indústrias, portos secos, terminais petrolíferos e químicos.

Não obstante, nas cidades brasileiras, o controle das formas urbanas é bastante negligenciado. A legislação impõe coeficientes de aproveitamento e taxas de ocupação, mas, em regra, o resultado volumétrico desses índices sequer é conhecido, como atestaram as oficinas de morfologia promovidas pelo Lab QUAPÁ. Os impactos em relação à vizinhança, ao relevo, aos rios e às vistas para a paisagem são pouco controlados pelo Estado e pela sociedade e, muitas vezes, percebidos somente após a implantação dos empreendimentos.

Essa ausência leva a uma configuração urbana que somente pode ser explicada segundo lógicas do mercado imobiliário, que pode atuar de modo intenso em certos setores da cidade e em outros momentos 
se espraiar por diversos pontos do tecido urbano. A verticalização tem se apresentado por diversos pontos das cidades de médio e grande porte, apesar de ainda se concentrar em áreas tradicionais de atuação das empresas de capital imobiliário. 0 adensamento construtivo é regra nas cidades de médio e grande porte. 0 adensamento (construtivo e populacional) nem sempre é acompanhado pela necessária ampliação do sistema de espaços livres públicos, em especial das áreas de lazer e das calçadas.

Nesse contexto de planejamento urbano frágil, no qual alguns agentes constroem formas urbanas sem a aprovação do poder público e outros conseguem impor interesses particulares para gerar as formas que lhes são convenientes e lucrativas, o que se percebe é que o ente público não é depositário da confiança do conjunto dos agentes como o regulador da forma urbana. Mas se o desenho urbano e os controles são ineficazes, como pode o planejamento urbano contribuir para a melhoria das cidades?

Diversas linhas de estudos e pesquisas passam a enfocar os problemas habitacionais e os processos e as políticas públicas. 0 Prof. Silvio Macedo e o grupo de pesquisadores reunido por ele propõem o estudo da forma urbana e dos espaços livres em oficinas de diagnóstico, as quais vão buscar identificar as formas, o papel da legislação na configuração destas, os agentes públicos e privados e o seu papel para o entendimento das transformações urbanas. Silvio Macedo defende o conhecimento das cidades brasileiras a partir de sua materialidade, não dos modelos ou fórmulas urbanísticas. A partir disso, podem ser identificadas oportunidades para propostas de intervenções e para novas formas de atuação do urbanista e do paisagista.

Nesse percurso, o Lab QUAPÁ criou método para a elaboração de cartografia temática específica, em GIS, sempre em aperfeiçoamento. As pesquisas QUAPÁ-SEL registraram significativas transformações nas cidades analisadas nas duas últimas décadas, entre elas a desconcentração das atividades centrais e industriais, o espraiamento urbano e funcional, o surgimento de bairros horizontais e verticalizados, as conurbações, a expansão da malha viária, o aumento expressivo do número de parques e áreas preservadas e os recorrentes desequilíbrios na distribuição de equipamentos públicos. Houve grande avanço no conhecimento dos agentes que constroem e direcionam a produção da forma urbana, o papel do Estado nas suas diversas instâncias e da iniciativa privada.

\section{Antecedentes}

O ensino de paisagismo na FAUUSP data dos anos 1950, quando veio dos Estados Unidos o Prof. Roberto Coelho Cardozo. Entre suas alunas, Miranda Magnolli e Rosa Kliass, já arquitetas, contribuíram, desde os anos 1960, para ampliar o escopo da atuação paisagística no Brasil. No início dos anos 1970, Miranda Magnoli começou a lecionar na FAUUSP, primeiro, a disciplina de Projeto de Edificações; em seguida, de Paisagismo, fortalecendo os estudos e pesquisas sobre paisagem, ambiente e paisagismo nessa escola, criando o Grupo de Disciplinas Paisagem e Ambiente, no âmbito da graduação (início dos anos 1980), e, com os colegas de tal grupo, a Área de Concentração Paisagem e Ambiente no Programa de Pós-Graduação em Arquitetura e Urbanismo (anos 1990).

Magnoli foi pioneira na FAUUSP ao vincular, no final dos anos 1970, as questões ambientais ao ensino de paisagismo. 0 que hoje parece óbvio, a indissociabilidade entre ambiente, paisagem e paisagismo, não se cogitava no país daqueles anos de ditadura militar e de expansão desmedida da fronteira agrícola, desprezando biomas florestais e de cerrado.

Em 1983, ao defender sua tese de livre-docência, Magnoli definiu espaço livre como todo espaço livre de edificações ou livre de urbanização, bem como advogou que a paisagem, o ambiente e todos os espaços livres se constituíam em objeto de interesse do campo profissional do paisagismo, seja no nível do projeto, do planejamento ou das políticas públicas. Foram ampliados, dessa maneira, o ensino e a pesquisa, bem como o campo profissional do arquiteto, no âmbito do paisagismo, para muito além do jardim ou do projeto com o uso de vegetação.

Com a criação do Grupo de Disciplinas e da Área de Concentração Paisagem e Ambiente, as inter-relações entre os campos da arquitetura, do urbanismo e do paisagismo se fizeram, na FAUUSP, de forma cada vez 
mais rica e dialética, sem estabelecer limites rígidos entre os referidos campos disciplinares, todos fundamentais para a formação do arquiteto e urbanista.

Um dos primeiros auxiliares da Profa. Miranda Magnoli, no início dos anos 1970, foi o Prof. Silvio Soares Macedo. Ambos foram responsáveis pelas primeiras pesquisas de morfologia urbana com ênfase nos espaços livres na FAUUSP, e tais pesquisas tiveram rebatimento no ensino de graduação e de pós-graduação, fossem em disciplinas obrigatórias ou optativas. A compreensão dos tecidos urbanos da metrópole de São Paulo, a verticalização, a desequilibrada distribuição de espaços livres públicos voltados ao lazer e convívio, suas dimensões e escalas de abrangência foram alguns dos temas que relacionavam paisagem e morfologia urbana em diversas dissertações de mestrado e teses de doutorado, a começar pelo estudo da evolução urbana do bairro de Higienópolis e de sua morfologia, dissertação de mestrado do Prof. Silvio Macedo (1982), "Mutação do espaço urbano: o bairro de Higienópolis e arredores", de 1982, bem como sua tese de doutorado, "São Paulo, paisagem e habitação verticalizada: os espaços livres como elementos de desenho urbano", concluída em 1988, cujas discussões sobre os espaços livres e edificados resultantes do processo de verticalização paulistano são até hoje relevantes (Macedo, 1988).

Magnoli e Macedo correlacionaram, na teoria e na prática, acadêmica e profissional, os conceitos de paisagem, forma urbana, desenho urbano e paisagismo. Nos anos 1980, nos célebres Seminários sobre Desenho Urbano no Brasil (SEDURs), promovidos pela Universidade de Brasília (UnB), é forçoso observar que a participação da FAUUSP se deu apenas por docentes e pesquisadores do Grupo de Disciplinas Paisagem e Ambiente (GDPA), e não por docentes do Grupo de Disciplinas de Planejamento Urbano e Regional (GDPL), indicando, desde aquela década, que o campo disciplinar do desenho urbano e dos estudos morfológicos mais se desenvolveria na FAUUSP pela área de paisagem e ambiente do que pela área de planejamentos urbanos, exceção parcial feita ao subtema da habitação de interesse social (HIS), em que o GDPL é importante referência nacional.

O papel estrutural da disciplina de Paisagismo no curso de graduação da FAUUSP é tributário de Magnoli e Macedo. A grade compreende uma disciplina obrigatória no primeiro ano, que é realizada em dois dias da semana, uma no terceiro e outra no quarto ano, além das disciplinas optativas. No primeiro e quarto anos, os alunos trabalham exercícios de morfologia urbana e espaços livres (Figuras 1 a 3).

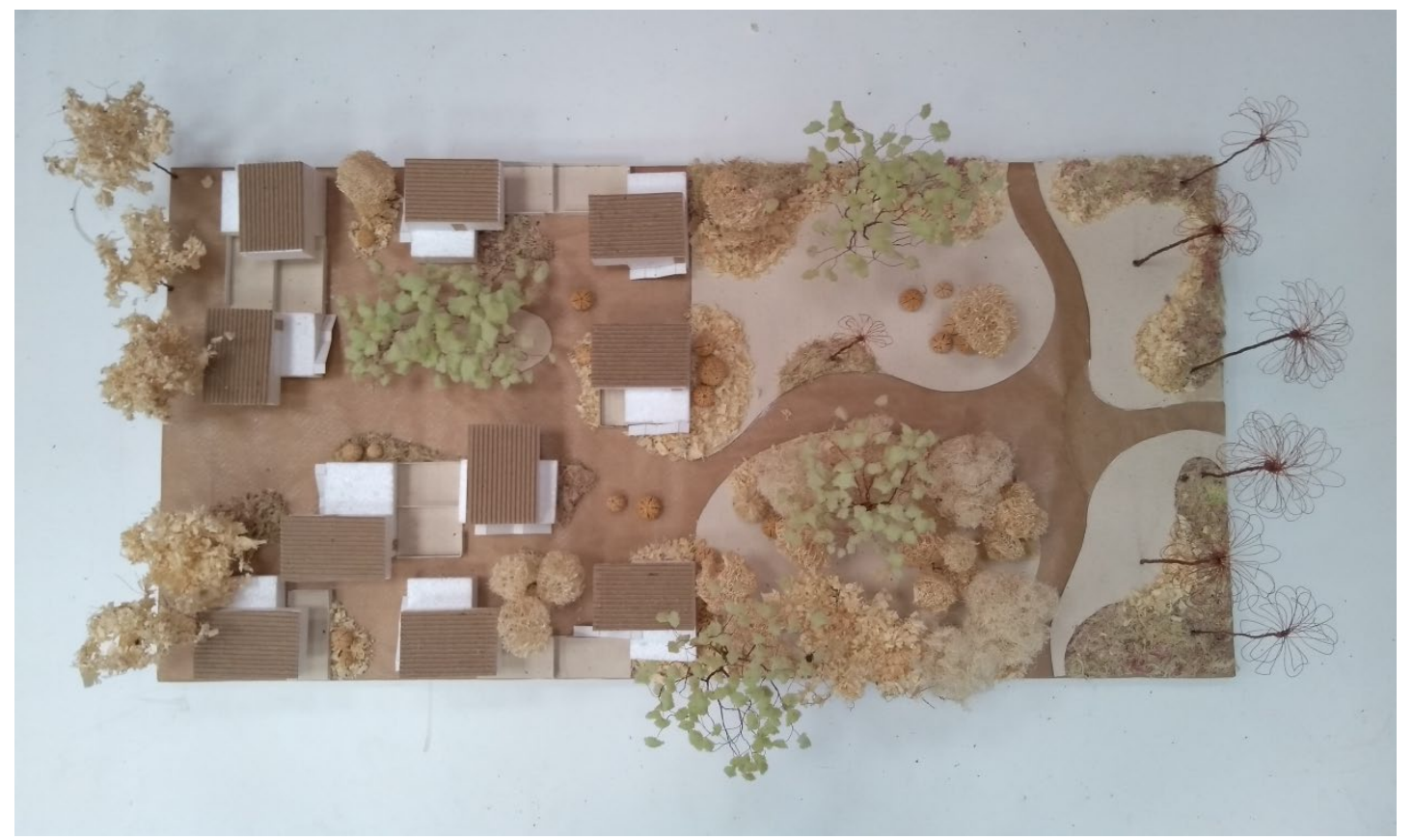

Figura 1 - Maquete de exercício do primeiro ano (2018) da disciplina Arquitetura da Paisagem, em que os alunos projetam, simultaneamente, um trecho de parque e de espaço de moradia com cerca de 20 unidades. Esse exercício é instrumental para o posterior, que consiste em projetar edificações e espaços livres em um bairro da cidade de São Paulo. Fonte: Acervo da disciplina AUP 0650. 


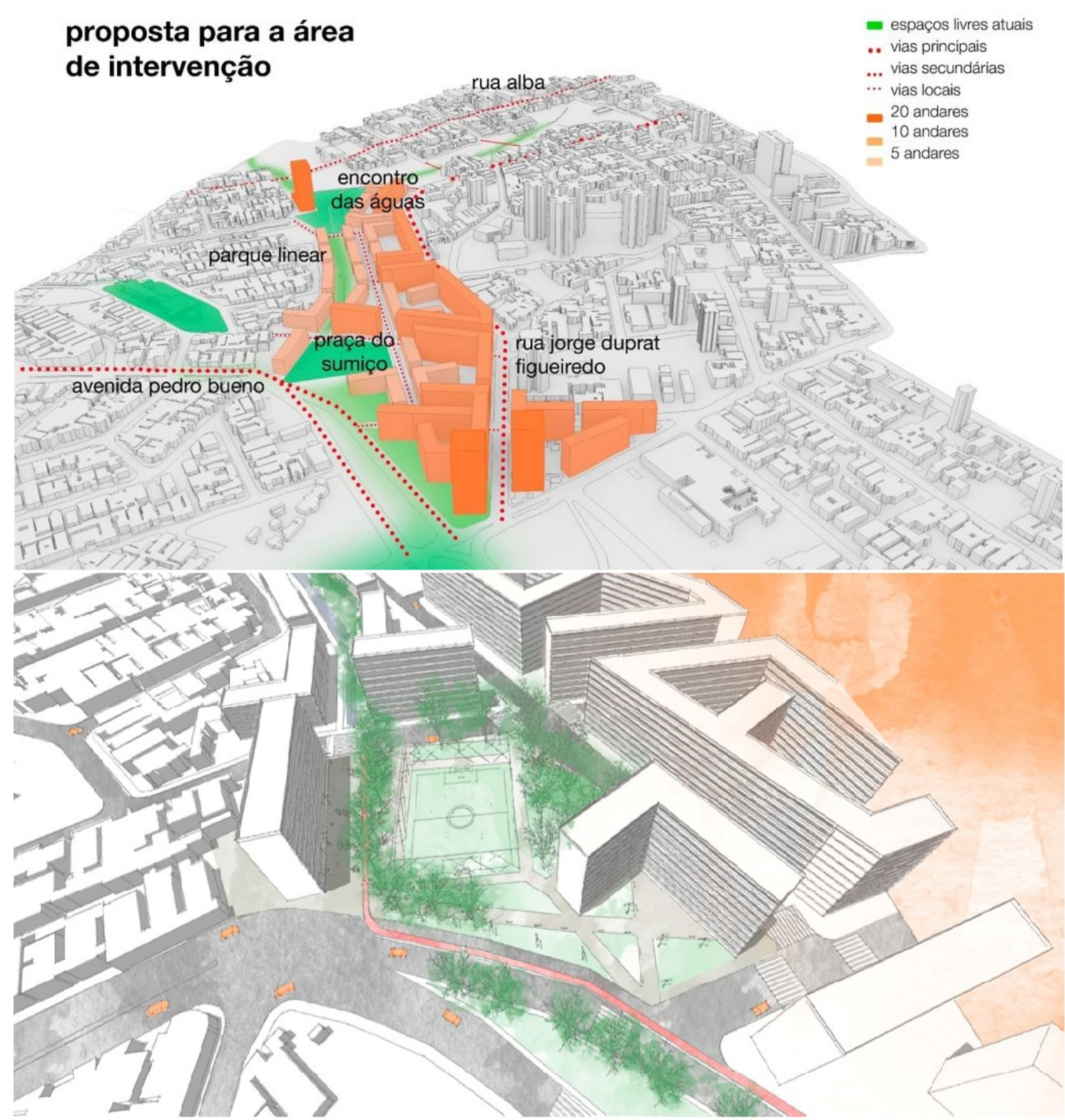

Figuras 2 e 3 - Projeto para terrenos desapropriados pela OUCAE (Operação Urbana Consorciada Águas Espraiadas) da equipe de Isabela Billi, Isabela Portinari, Pedro Simplício, Beatriz Moraes, Chiara Bussani, Catherine Beatriz e Bruna Gil Ferreres, para a disciplina AUP 0654 - Projeto da Paisagem (4 Ano) de 2018. Fonte: Acervo da disciplina AUP 0654.

A livre-docência do Prof. Silvio Macedo (1993), "Paisagem, urbanização e litoral: do Éden à cidade", defendida em 1993, tratou da ocupação do litoral brasileiro, em especial dos Estados de São Paulo, Santa Catarina, Bahia e Rio Grande do Norte, que abarcam ecossistemas muito variados e sensíveis. Nesses litorais há grandes e pequenas cidades, praias desertas e em diversos graus de apropriação econômica e turística. Silvio Macedo fez uso de sobrevoos e fotos aéreas para analisar os tecidos urbanos, sua relação com as bases geofísicas e distinguir os tipos e processos de ocupação. Na banca de avaliação desse trabalho, Milton Santos ressaltou que a identificação daqueles padrões, que então se apresentavam como quase uma constatação da realidade, eram o mérito e a força do trabalho, porque tornaram óbvio o que estava sob os olhos de todos, mas que escapava deles.

Diversos trabalhos de pós-graduação foram desenvolvidos com o tema da ocupação dos litorais sob a coordenação de Macedo e também uma colaboração com o Projeto Orla, do Ministério do Meio Ambiente, que buscou capacitar o corpo técnico das administrações municipais e organizações da sociedade civil a 
desenvolver projetos para a ocupação mais ordenada no litoral. No início dos anos 1990, estava em curso um processo de descentralização administrativa, e o Governo Federal transferia atribuições de gestão local para os municípios. Silvio Macedo foi responsável por coordenar a elaboração de cartilhas, manuais e cursos com metodologias para leitura das unidades de paisagem, diagnóstico, identificação de problemas e conflitos e proposições.

Em 1994, Silvio Macedo criou o Laboratório da Paisagem e iniciou projetos de pesquisa sobre o “Quadro do Paisagismo no Brasil" (QUAPÁ). Entre 1994 e 2005, o QUAPÁ dedicou-se a levantar parques, praças e calçadões em 15 cidades brasileiras, que depois se tornaram 22. Os pesquisadores da FAUUSP viajavam pelo país para pesquisar os acervos de projetos das prefeituras e governos de Estado e para visitar in loco, desenhar e fotografar os projetos que encontravam implantados. A diversidade era muito grande, tanto em relação à qualidade quanto à estrutura de manutenção, mas, em todo o país, a apropriação de espaços livres qualificados para o lazer apontava para a importância desse trabalho. Naquela época, sem internet, projetos paisagísticos em cidades como Campo Grande ou João Pessoa eram mais distantes e desconhecidos para os arquitetos do Sul e Sudeste do Brasil que Barcelona ou Tóquio, fartamente retratadas nas revistas de arquitetura e paisagismo. A pesquisa conduzida por Silvio Macedo revelou a existência da produção brasileira de arquitetura paisagística, com pontos comuns com a produção internacional e com muitas particularidades.

Três livros foram publicados: Quadro do Paisagismo no Brasil (1999), Parques Urbanos no Brasil (Macedo \& Sakata, 2002), de Silvio Macedo e Francine Sakata, e Praças Brasileiras, de Macedo \& Robba (2002). Em pouco tempo, tornaram-se bibliografia de cursos de paisagismo em escolas de arquitetura e urbanismo, reflexo da escassez de material.

O QUAPÁ chegava a reunir duas dezenas de pesquisadores, especialmente graduandos, que trabalhavam no desenho de praças, parques e calçadões e na organização das fotografias e também em pesquisas individuais que discutiam e analisavam esses espaços, agrupados por tipos ou por cidades. O Prof. Silvio Macedo formava, assim, uma geração de pesquisadores, professores e de arquitetos paisagistas atuantes.

\section{Os projetos temáticos QUAPÁ-SEL}

A partir de 2006, o Laboratório da Paisagem da FAUUSP, atualmente denominado Laboratório Quadro do Paisagismo no Brasil (Lab QUAPÁ - FAUUSP), deixou de enfocar projetos de espaços livres isolados e passou a se dedicar às pesquisas sobre sistemas de espaços livres (SEL) urbanos. Essa abordagem mais ampla e sistêmica guarda similaridades com as desenvolvidas anteriormente por McHarg (1969), inclusive em relação aos procedimentos de overlay, Spirn (1995), Hough (2004), entre outros.

Mas se havia limitações para estudar e descrever parques e praças de cidades de regiões distantes, tratar das relações entre os espaços livres e as questões de processo de produção e de gestão seria impossível sem a parceria de pesquisadores locais.

Para a pesquisa sobre SEL de cidades brasileiras significativas do processo de urbanização, a abrangência e a complexidade do tema levaram o Lab QUAPÁ à constituição da Rede Nacional de Pesquisa QUAPÁ-SEL ${ }^{1}$, entendendo que somente um esforço coletivo maior, uma pesquisa em rede, possibilitaria se aproximar empiricamente do objeto de estudo ${ }^{2}$. Assim, a pesquisa se realizou por meio de múltiplas abordagens que, entre 2006 e 2018, incluíram:

\footnotetext{
${ }^{1}$ A Rede QUAPÁ-SEL é uma rede de pesquisa aberta, provavelmente a maior do Brasil, na área de Arquitetura e Urbanismo, contando com pesquisadores de todas as macrorregiões do país, atualmente das seguintes instituições: UFAM, UNIFAP, UFPA, UFT, UEMA, UNIFOR, UFRN, UFCG, UFPE, UFAL, UFES, UFMG, UFU, UFRJ, IFF, USP, PUC-Campinas, UFPR, UEM, UFSC, UNESC, UNOESC, UFRGS, UFSM, UFFS, UnB, UEG e UFMS.

${ }^{2}$ Foram pesquisadas mais de 30 cidades/metrópoles de todas as macrorregiões do país, entre as principais delas estão: Rio Branco (AC), Manaus (AM), Belém (PA), Macapá (AP), Palmas (TO), São Luís (MA), Fortaleza (CE), Natal (RN), Recife (PE), Campina Grande (PB), Maceió (AL), Salvador (BA), Vitória (ES), Belo Horizonte (MG), Uberlândia (MG), Rio de Janeiro (RJ), Campos dos Goytacazes (RJ), São
} 
- Revisão bibliográfica, discussão e proposição conceitual;

- Produção de cartografia temática específica realizada, sobretudo, a partir de análise visual de imagem de satélites (exemplos nas Figuras 4 a 12);

- Análises cartográficas comparativas;

- Sobrevoos e levantamentos fotográficos;

- Estudos sobre legislações urbanísticas e ambientais;

- Ensaios volumétricos a partir de índices urbanísticos dispostos em leis de ocupação do solo;

- Oficinas de pesquisa realizadas em cada uma das cidades investigadas;

- Realização de colóquios anuais da Rede QUAPÁ-SEL.

Entre 2007 e 2018, o Lab QUAPÁ, coordenado pelo Prof. Silvio Macedo³, realizou dois grandes projetos temáticos de pesquisa sobre SEL contando com apoios da FAPESP e do CNPq, tendo submetido novo projeto temático à FAPESP em 2019. Os mencionados projetos se intitulam:

- Os sistemas de espaços livres e a constituição da esfera pública contemporânea no Brasil - QUAPÁ-SEL I (2007-2011);

- Os sistemas de espaços livres na constituição da forma urbana contemporânea no Brasil: produção e apropriação - QUAPÁ-SEL II (2012-2018);

- Os sistemas de espaços livres na transformação contemporânea da paisagem brasileira: políticas e projetos - QUAPÁ-SEL III (previsto para o período 2020-2024).

Paulo (SP), Santos (SP), Campinas (SP), São José dos Campos (SP), São Carlos (SP), Ribeirão Preto (SP), Sorocaba (SP), Curitiba (PR), Maringá (PR), Florianópolis (SC), Criciúma (SC), Porto Alegre (RS), Santa Maria (RS), Brasília (DF), Goiânia (GO), Anápolis (GO) e Campo Grande (MS).

${ }^{3}$ Desde sua criação, o Lab QUAPÁ sempre foi coordenado pelo Prof. Silvio Macedo, tendo sido vice-coordenado pelo Prof. Eugenio Queiroga entre 2006 e 2018 e, a partir de 2019, a vice-coordenação foi assumida pelo Prof. Fabio Gonçalves, todos do GDPA-FAUUSP. Diversos pesquisadores de todos os níveis acadêmicos compuseram os quadros do Lab QUAPÁ, realizando iniciações científicas, mestrados, doutorados e pós-doutorados. Entre os principais pesquisadores do período 2006-2019 merecem destaques: Dra. Ana Cecília Campos, Arqta. Fany Galender, Dr. Fabio Robba, Dra. Francine Sakata, Dra. Helena Degreas, Dr. João Meyer, Dr. Leonardo Coelho, Dra. Mayumi Hirye, Dr. Rogério Akamine, Dra. Vanderli Custódio e Dra. Verônica Donoso. 
4. Aspectos Morfológicos da Região Metropolitana de São Paulo - Parques, Praças, Cemitérios e Orlas
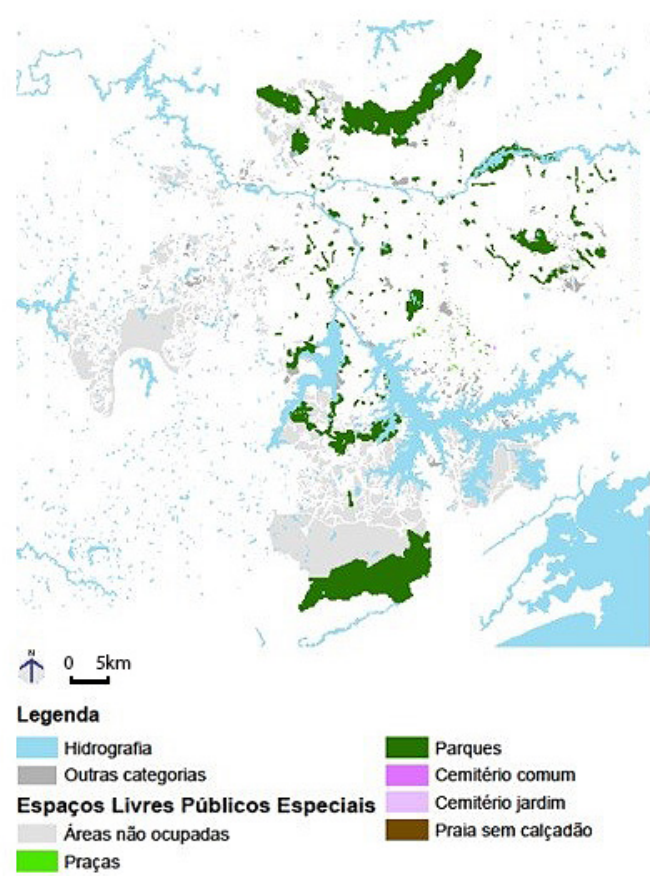

6. Aspectos Morfológicos da Região Metropolitana de São Paulo - Recuos Intraquadra

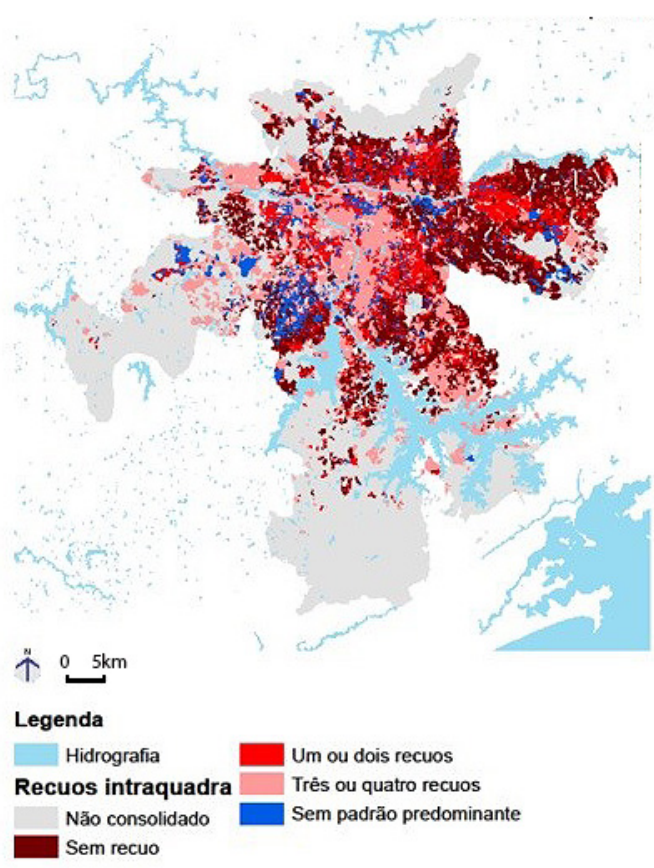

5. Aspectos Morfológicos da Região Metropolitana de São Paulo - Espaços Livres Intraquadra

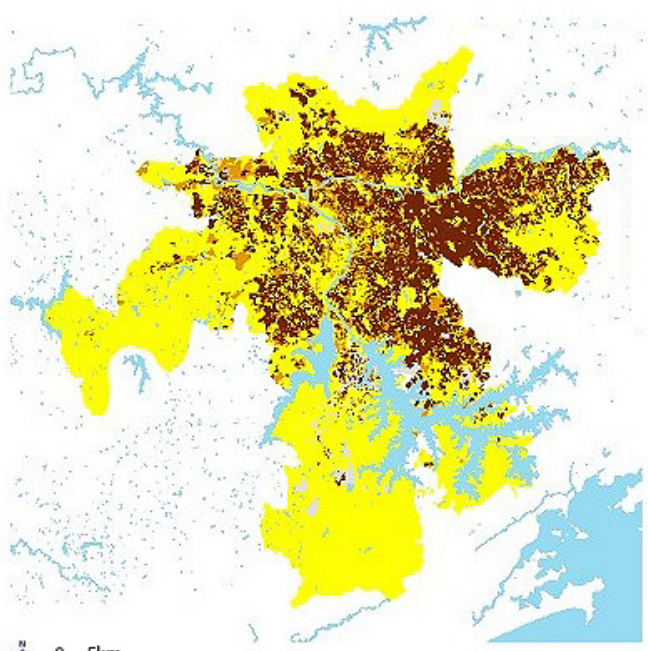

$\stackrel{n}{\uparrow} 5 \mathrm{~km}$

\section{Legenda}

\begin{tabular}{l|l}
$\square$ Hidrografia & $0-30 \%$ \\
Espaços Livres Intraquadra & $30 \%-50 \%$ \\
Náo consolidado & $50 \%-100 \%$
\end{tabular}

7. Aspectos Morfológicos da Região Metropolitana de São Paulo - Arborização Intraquadra

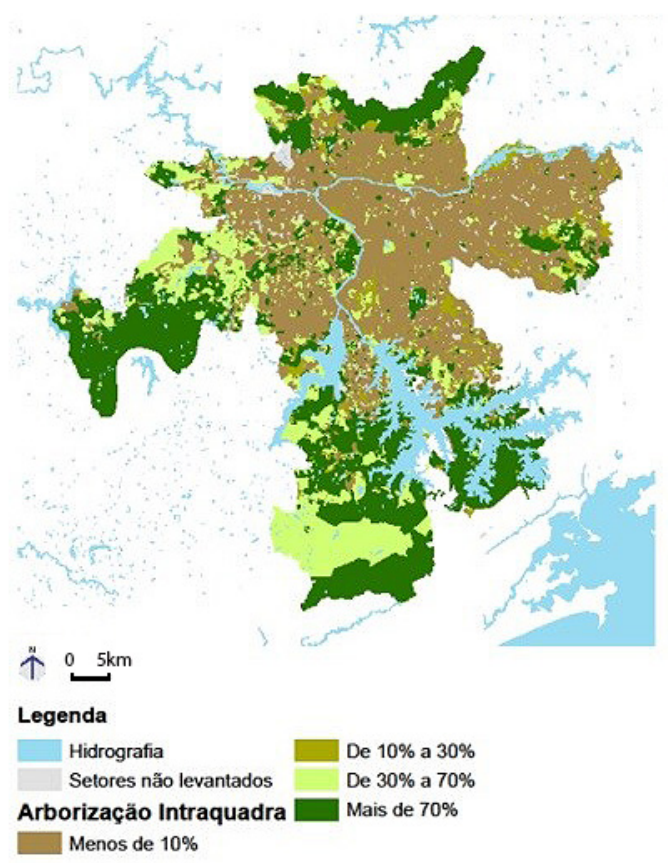

Figuras 4 a 7 - Cartografia temática para parcela da Região Metropolitana de São Paulo, Lab QUAPÁ, 2014. 


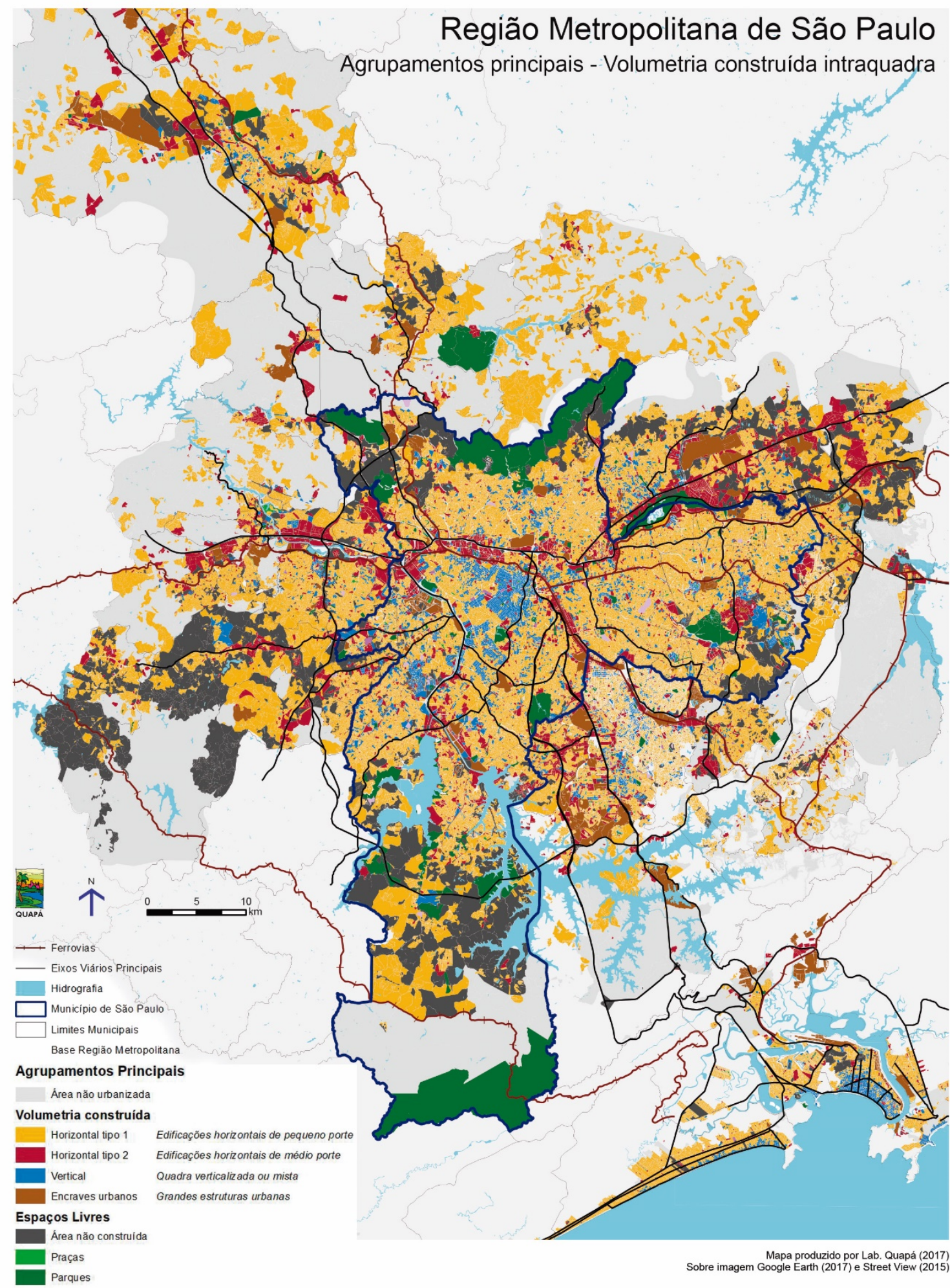

Figura 8 - Cartografia temática para parcela da Região Metropolitana de São Paulo, Lab QUAPÁ, 2014. 

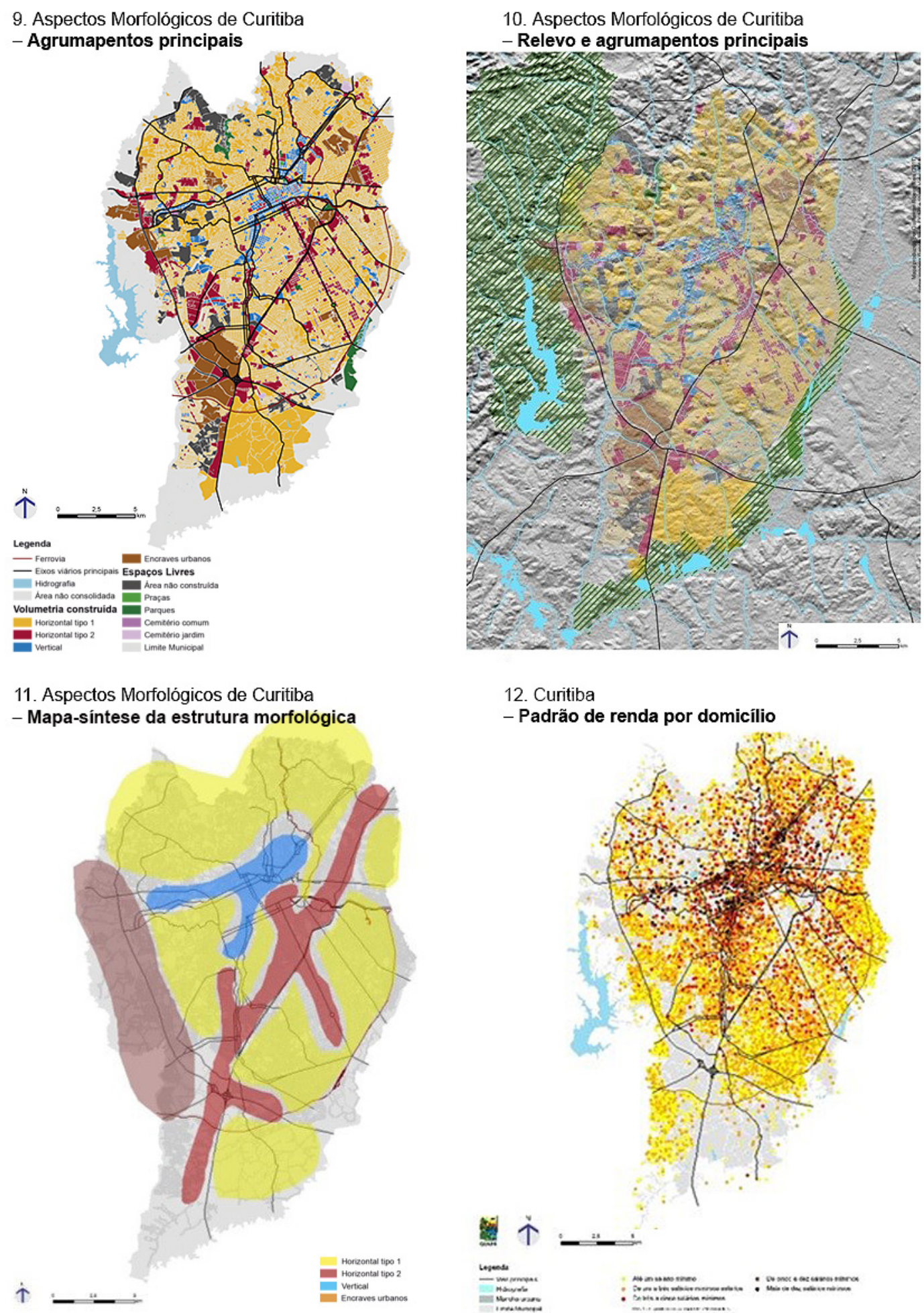

Figuras 9 a 12 - Cartografia temática produzida para o município de Curitiba, Lab QUAPÁ, 2009-2011.

Será discorrido brevemente a seguir sobre as oficinas e colóquios que alimentaram a pesquisa, fundamentação teórica desenvolvida durante o QUAPÁ-SEL I que vem sendo utilizada nos estudos morfológicos do Lab QUAPÁ; em seguida, serão apresentados resultados gerais da pesquisa QUAPÁ-SEL II a respeito das formas urbanas das cidades e metrópoles brasileiras estudadas. 


\section{As oficinas e os colóquios QUAPÁ-SEL: pesquisa e difusão científica}

As interlocuções entre membros da Rede QUAPÁ-SEL nos projetos temáticos de pesquisa têm sido feitas por meio de oficinas de pesquisa e colóquios anuais, nos quais os pesquisadores têm a oportunidade de se reunir e conhecer com propriedade a forma urbana brasileira, seus processos de formação, estruturação e transformação morfológica, dentro da realidade contemporânea nacional - em especial das duas primeiras décadas do século XXI.

As oficinas têm como finalidade o conhecimento local, da dimensão e da distribuição dos espaços livres, a compatibilização do entendimento dos pareceres dos estudiosos locais com o entendimento preliminar do grupo de pesquisa e o embate entre visões e análises mais localizadas e, portanto, parciais. Isso tudo possibilita uma síntese que permite o entendimento da complexidade urbana e da estrutura morfológica da cidade.

Nas oficinas, esperava-se:

- Caracterizar o sistema de espaços livres na forma urbana do município;

- Compreender o papel dos espaços livres na constituição da produção da forma urbana contemporânea;

- Compreender o papel da legislação ambiental e urbanística na produção dos espaços livres e forma urbana;

- Compreender o papel concreto dos agentes responsáveis pela produção contemporânea dos espaços livres e edificados no município;

- Discutir procedimentos de leitura e análise crítica referentes à temática da pesquisa;

- Discutir critérios que pudessem subsidiar políticas públicas referentes à produção e apropriação de espaços livres e forma urbana.

Antes da realização dos encontros, eram levantados dados demográficos e elaborados, no Lab QUAPÁ, mapas da estruturação morfológica das cidades em estudo (Figuras 4 a 12). Pesquisadores e técnicos das prefeituras locais eram convidados a participar. As oficinas eram abertas por palestrantes convidados, que traziam insumos das políticas e dos novos investimentos em andamento, feitos tanto pelo Poder Público como pela iniciativa privada. Até 2018, os participantes, após as palestras, eram divididos em quatro grupos que deveriam reunir dados e analisar os temas: (1) sistemas de espaços livres; (2) padrões morfológicos; (3) agentes produtores da forma urbana; e (4) formas urbanas propostas pela legislação. Era obtido, assim, em tempo reduzido, um retrato amplo da cidade em questão.

Ao final de mais de 50 oficinas realizadas naquele período, houve avanço coletivamente em relação ao conhecimento das cidades, de seus espaços livres e formas urbanas, associando-os aos agentes produtores e gestores dos espaços livres e edificados, públicos e privados.

\section{QUAPÁ-SEL I: conceitos fundamentais}

O conceito de espaço construído ao longo da obra de Milton Santos $(1978,1985,1996)$ permite compreendê-lo como instância social, ou seja, cabe ao espaço um valor ativo diante do processo social; logo, a dialética social é dialética socioespacial. Para Santos (1996), o espaço é um híbrido, constituído na indissociabilidade entre o sistema de objetos e o sistema de ações, entre fixos e fluxos, entre materialidade e sociedade ${ }^{4}$. Assim, o espaço é sempre presente (a ação só se constitui no tempo

\footnotetext{
${ }^{4}$ Para a geografia crítica, perspectiva adotada pelo Lab QUAPÁ, não se confunde espaço com lugar. Segundo Milton Santos (1978, 1996), o espaço se refere ao todo, constituído no processo histórico e dialético, ao passo que o lugar se refere à parte. Para Armando Corrêa da Silva (1986), lugar, região e território são categorias analíticas internas ao espaço.
} 
presente), inclui o pretérito, o trabalho materializado em "próteses" sobre o suporte biofísico, bem como o vir a ser, na medida em que as ações (humanas) visam ao futuro, imediato ou distante.

Em 1982, Miranda Magnoli, em sua tese de livre-docência, buscou consolidar, de maneira ampla, o campo profissional e de formação paisagística a partir do seu objeto central: o espaço livre. Para Magnoli (1982), os espaços livres são todos os espaços abertos, livres de edificação, incluindo, portanto, ruas, praças e parques, mas também pequenos pátios descobertos, quintais, rios, matas, campos produtivos, dunas etc.

Magnoli dizia que o espaço é sempre interescalar, assim como Milton Santos (1985) deixou claro que não se pode abstrair um recorte espacial do espaço como um todo; assim, o lugar é sempre lugar no/do mundo. Tem-se, portanto, um princípio do método dialético espacial para o estudo dos subespaços, sejam eles regiões, cidades ou "simples" praças.

É possível relacionar a teoria da complexidade de Morin (2008) com a geografia crítica de Santos e as contribuições de Magnoli para o estudo e projeto dos espaços livres. A noção moriniana de sistema (um objeto complexo estruturado, dinâmico e aberto, um sistema de sistemas) encontra paralelo na noção de totalidade espacial (Santos, 2005) e magnoliana de interescalaridade.

A partir dessa fundamentação teórica, o Lab QUAPÁ afirma (Macedo et al., 2018) que toda a cidade possui um SEL, visto que tem, ao menos, um sistema viário (lembrando que ruas e avenidas são espaços livres) que conecta não apenas os endereços privados, mas também os demais espaços livres públicos (praças, parques, orlas etc.). Também o conjunto de espaços livres privados, mesmo que não conectados diretamente pelo sistema viário, interage socioambientalmente, ainda que de forma indireta, com o sistema de espaços livres públicos (Queiroga, 2012). Assim, o SEL da cidade, do município, da região, metropolitana ou não, inclui todos os espaços livres, privados ou públicos, voltados para práticas sociais ou para a conservação ambiental, produtivos ou destinados ao ócio.

Portanto, como princípio de método, não deve ser isolado um espaço livre para melhor compreendê-lo; pelo contrário, é preciso investigá-lo à luz de sua inserção no SEL; de maneira análoga, uma proposição para um espaço livre não pode se descuidar do papel, presente e futuro, que o espaço livre em questão possui ou possuirá no SEL. Em uma perspectiva sistêmica e dialética, também não se pode isolar o SEL do meio, urbano ou regional, em que ele está inserido. O SEL é parte integrante da produção social do espaço e intrínseca a ela. A forma urbana é constituída, então, enquanto síntese dinâmica entre o sistema de espaços livres e o conjunto de espaços edificados sobre o suporte biofísico.

Falar sobre espaços livres e forma urbana significa falar sobre a estruturação da cidade, em especial das formas urbanas construídas sobre o suporte biofísico, elementos fundamentais dos aspectos materiais das paisagens urbanas. A partir do estudo dos SEL, pode ser compreendida a influência deles na constituição da estrutura urbana e na forma da mancha urbana, bem como os diferentes tipos e funções dos espaços livres. Os SEL influenciam em diversas escalas do cotidiano urbano, seja para a realização de práticas sociais (circulação, lazer, atividades físicas, festas e manifestações políticas), seja para questões de drenagem e conservação de dinâmicas ecológicas.

O escopo do estudo da forma urbana a partir dos SEL permite uma leitura e um entendimento da transformação da cidade que se dá de modo contínuo, ora mais intenso, ora mais discreto. Segundo Panerai et al. (1999), a cidade é constante, mutável, e sua configuração atual é apenas um instante precário e transitório de sua evolução.

\section{QUAPÁ-SEL II: alguns resultados gerais sobre a forma urbana contemporânea brasileira}

0 objeto principal da pesquisa foram capitais de Estados $^{5}$, dada sua relevância na rede urbana, bem como pela difusão da cultura urbanística e do planejamento urbano nelas praticadas para as cidades médias. Várias cidades médias interioranas foram também estudadas, assim como cidades que

\footnotetext{
${ }^{5}$ Rio Branco (AC), Manaus (AM), Belém (PA), Macapá (AP), Palmas (TO), Fortaleza (CE), Natal (RN), Recife (PE), Maceió (AL), Salvador (BA), Vitória (ES), Belo Horizonte (MG), Rio de Janeiro (RJ), São Paulo (SP), Curitiba (PR), Florianópolis (SC), Porto Alegre (RS), Campo Grande (MS), Goiânia (GO) e Brasília (DF). Capitais, portanto, de todas as macrorregiões do Brasil.
} 
compunham efetiva condição metropolitana, fosse por conurbação física e/ou funcional com as capitais, fosse mesmo metrópoles interioranas de escala regional ${ }^{6} .0$ recorte temporal envolveu as duas primeiras décadas do século XXI.

Para o caso das cidades estudadas, os processos de transformação mais evidentes são aqueles que se dão pela expansão da mancha urbana, em grande medida verificadas pela ampliação de suas bordas, ocupadas, sobretudo, por loteamentos fechados e condomínios para classes alta (Figura 13), média e de baixa renda, por exemplo, os empreendimentos vinculados ao Programa Minha Casa Minha Vida (PMCMV) - responsáveis, no período analisado, pela adição de importantes áreas ao tecido urbano de cidades médias brasileiras (Figura 14).

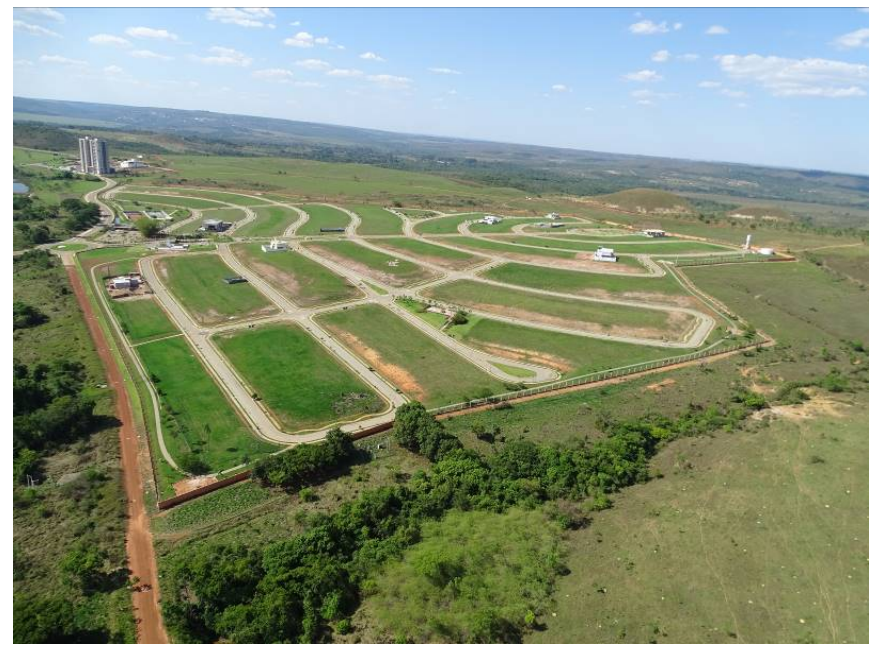

Figura 13 - Distrito Federal, loteamentos Alphaville em processo de ocupação, como muitos outros em diversas cidades do país. Foto: Silvio Macedo (2015).

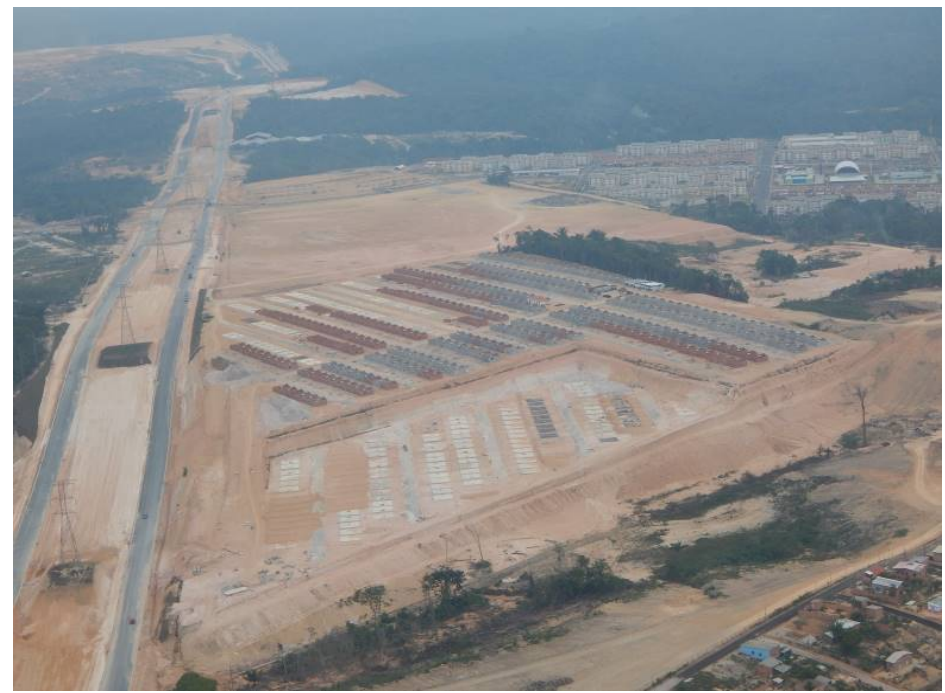

Figura 14 - Vista aérea da região norte de Manaus, com novas áreas habitacionais e futura ligação com a área central. Foto: Eugenio Queiroga (2015).

Nas grandes metrópoles, como São Paulo, Rio de Janeiro, Belo Horizonte e Salvador, desníveis de renda acentuados, associados ao alto custo da terra urbana e à falta de destinação de áreas para a moradia popular pelo Poder Público, acabam resultando em extensas áreas ocupadas por habitação informal, com

\footnotetext{
${ }^{6}$ Entre as principais cidades médias e metrópoles regionais estudadas destacam-se: Anápolis (GO), Campina Grande (PB), Campinas (SP), Campos dos Goytacazes (RJ), Criciúma (SC), Maringá (PR), Santa Maria (RS), Santos (SP), São José dos Campos (SP), Sorocaba (SP), Uberaba (MG) e Uberlândia (MG).
} 
espaços livres em geral limitados a ruas e um ou outro pequeno largo ou campinho de futebol, o que cria uma característica específica para tais áreas, densamente ocupadas, dentro do que se denomina genericamente como padrão periférico de urbanização. Não se trata apenas de carências decorrentes da baixa renda e dificuldade de acesso ao mercado imobiliário formal, mas também de geração de renda imobiliária no mercado informal, na medida em que se ocupa (taxa de ocupação) e se aproveita (coeficiente de aproveitamento efetivo) intensamente do solo, permitindo a venda de lajes ou mais de uma unidade habitacional no lote, ou ainda apenas cômodos de aluguel que se sobrepõem em situações precárias, ocupando áreas de risco quanto a inundações ou deslizamentos de terra.

As periferias das grandes cidades brasileiras, ao ocuparem áreas de maior declividade, geram um tipo morfológico específico, complexo, de edificações de múltiplos pavimentos, frequentemente como casas sobrepostas, com acessos ora independentes, ora comuns, autoconstruções que se ampliam lentamente ao longo do tempo, descendo e subindo encostas (Figura 15). As ruas são organicamente constituídas, desenhadas para receber, sobretudo, os automóveis; ônibus circulam com dificuldade, pedestres mais ainda, pois as exíguas calçadas se prestam mais a acessos a garagens nos lotes, gerando enormes desníveis para a circulação longitudinal e pública.

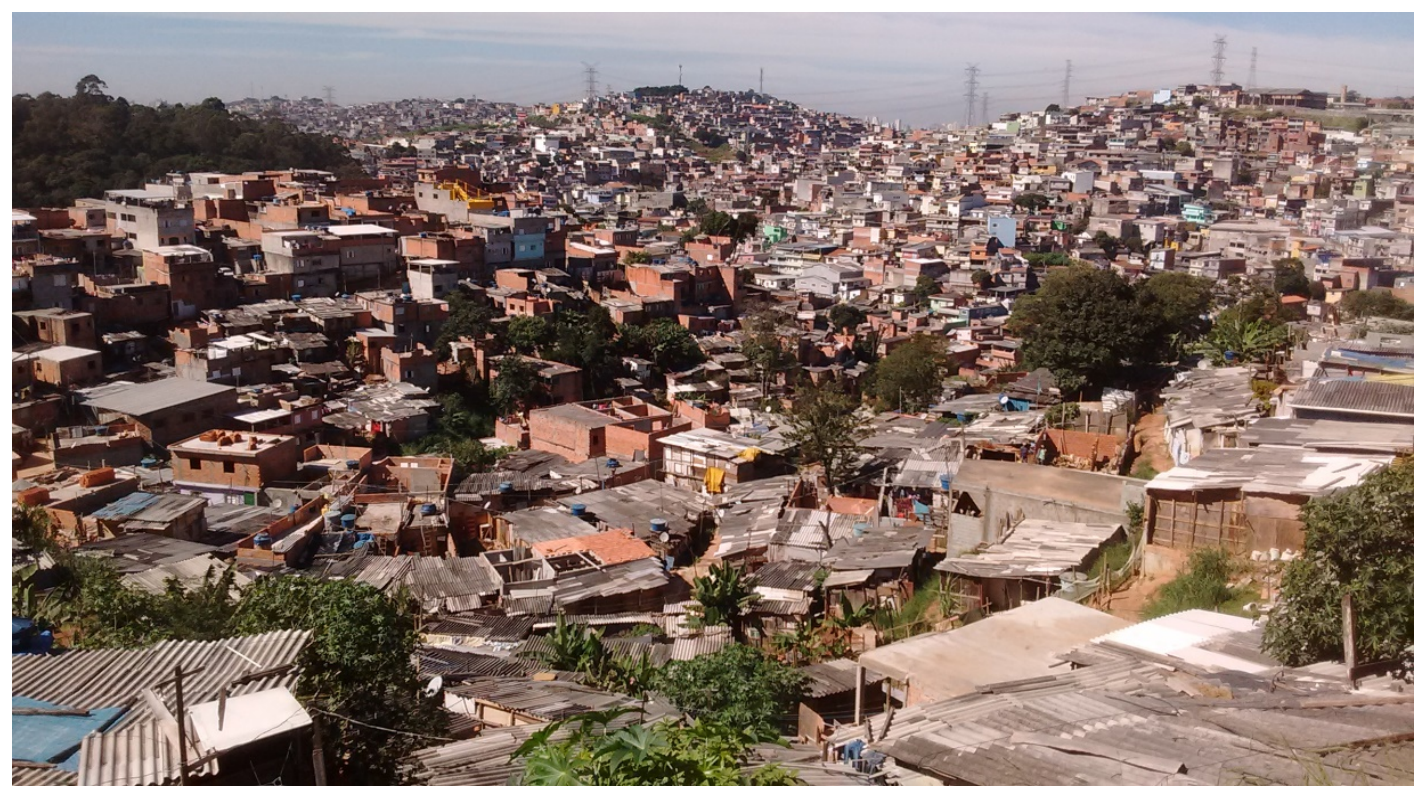

Figura 15 - Periferias no extremo norte da cidade de São Paulo: favelas, loteamentos clandestinos e loteamentos irregulares se misturam e constituem um tecido urbano típico do padrão periférico de urbanização. Foto: Eugenio Queiroga (2017).

No que tange às áreas periféricas das cidades médias pesquisadas, dado o custo da terra não tão elevado, seus tecidos urbanos são menos densos, os lotes são maiores e menos ocupados e aproveitados do que nas grandes metrópoles, com alguma presença de espaços livres, arborização e melhores condições de salubridade.

Nas duas décadas analisadas, apesar de o crescimento populacional ter sido moderado, a diminuição do número de habitantes por unidade habitacional criou forte demanda para a construção de novas unidades habitacionais. A verticalização respondeu, em particular nas grandes cidades brasileiras, por parte significativa dessa demanda, sobretudo para as famílias com capacidade de financiamento imobiliário. A maior parte dos edifícios de apartamento possui recuos, o que gera grande quantidade de espaços livres privados sobre lajes de estacionamento. Os edifícios e as pessoas se afastam gradativamente das ruas lindeiras, enfraquecendo a esfera de vida pública na escala do cotidiano habitacional. Em regra, ao longo do tempo, o adensamento construtivo e populacional não foi acompanhado da necessária ampliação do sistema de espaços livres públicos, em especial as áreas de lazer e convívio, assim como as calçadas e mesmo o leito carroçável não suportam adequadamente os 
novos fluxos. 0 processo de verticalização contemporâneo se espraia por inúmeros pontos das cidades de médio e grande porte, apesar de ainda manter concentrações maiores em áreas tradicionais de atuação das empresas de capital imobiliário (Figuras 16 e 17).

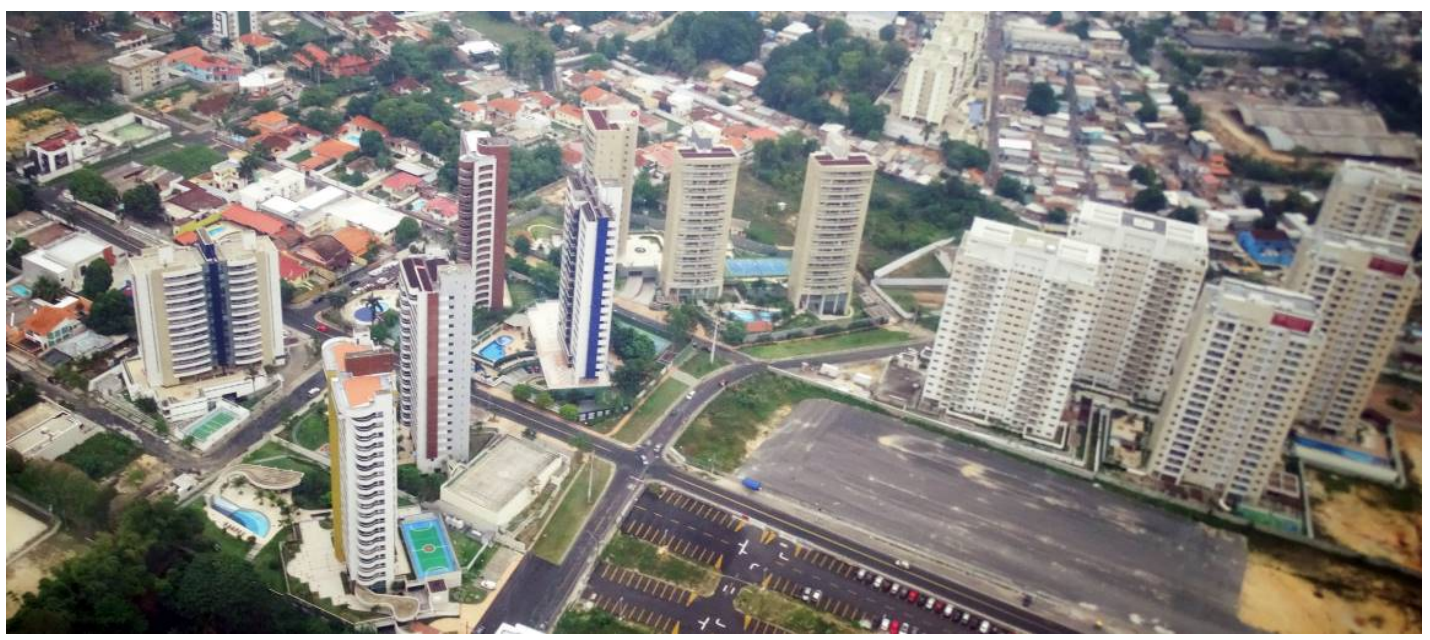

Figura 16 - Áreas residenciais em Manaus: cada empreendimento isolado tem seus espaços livres ocupados por equipamentos esportivos entremeados por áreas gramadas ou jardins. Foto: Silvio Macedo (2015).

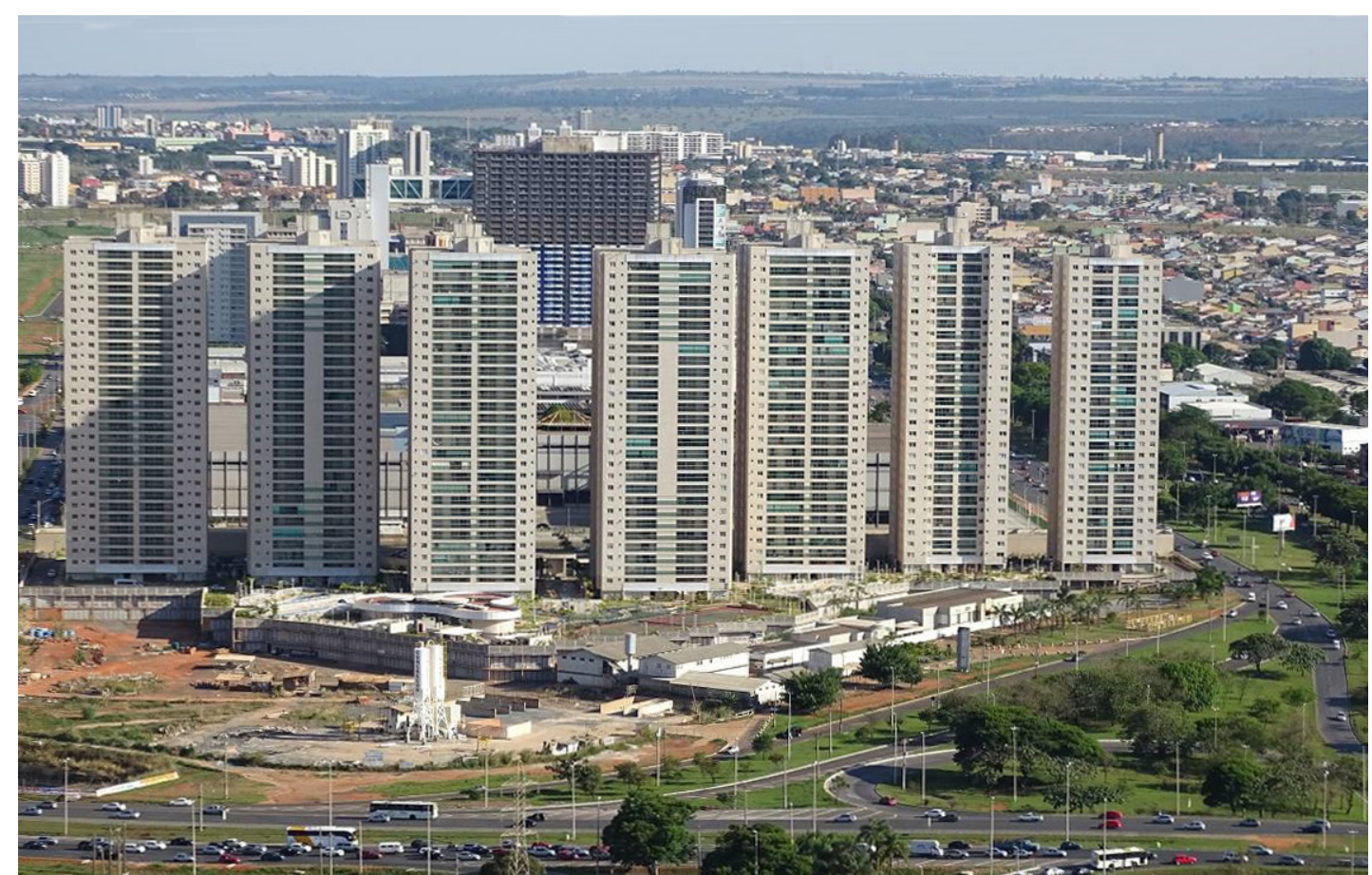

Figura 17 - Conjunto vertical em cidade-satélite, estrutura simular à encontrada em uma série de outras cidades, até a poucos anos impossível de se encontrar no Distrito Federal. Foto: Silvio Macedo (2015).

As cidades brasileiras investigadas são, ainda, predominantemente horizontais. Mesmo São Paulo não possui mais que $15 \%$ de suas quadras com presença de edifícios de quatro ou mais pavimentos, conforme levantamentos efetuados minuciosamente no Lab QUAPÁ (Queiroga, 2016). Essa horizontalidade está associada a um alto índice de ocupação do solo, em média superior a 50\% de taxa de ocupação, e o espaço destinado a jardins e quintais é frequentemente ocupado por acréscimos paulatinos das construções iniciais, ou seja, o espaço livre intralote é comumente espaço temporário, reserva a ser edificada.

Como resultado, há uma alta impermeabilização da quadra urbana e uma arborização que, em regra, não supera $10 \%$ do espaço intraquadra. A arborização urbana é, em geral, pouca e dispersa pelo tecido 
urbano. Grandes extensões de cobertura vegetal arbórea são somente encontradas em parques, praças e terrenos à espera de ocupação e eventuais áreas de conservação ambiental. Exceções maiores são encontradas em bairros de elite, nos quais calçadas mais largas são bem arborizadas.

\section{Considerações finais}

A forma urbana influencia na constituição da estrutura urbana, nas atividades, no cotidiano da cidade e nos sistemas de espaços livres. Diferentes tipos, quantidade, distribuição e qualificação dos espaços livres interagem em diversas escalas do cotidiano urbano, na drenagem, na conservação de dinâmicas ecológicas, na circulação e no lazer. Esse entendimento possibilita a identificação de conflitos e oportunidades de melhoria da qualidade urbana. Entretanto, na prática, nas cidades brasileiras, o projeto urbano/desenho urbano é negligenciado, com exceção das poucas cidades e áreas planejadas, como Palmas, capital do Estado de Tocantins; o bairro da Barra da Tijuca, no Rio de Janeiro; e os loteamentos residenciais fechados em muros, construídos ao redor de cidades, mas apartados delas. 0 projeto urbano seria um procedimento desejável, pois é fundamentado em uma concepção prévia de cidade e, portanto, de sua estrutura formal, que definiria a priori vias estruturais, eixos de drenagem, espaços de convívio e lazer, gabaritos e relações físicas entre edifícios, de modo que se estabeleçam relações formais de caráter estético, funcional e ambiental que possibilitariam melhor habitabilidade de áreas urbanas específicas. Os custos de instalação de qualquer infraestrutura após implantadas as ruas e edificações são muito mais altos, e o resultado é, comumente, inferior. Mesmo em Palmas, planejada desde seu início, o crescimento da cidade não respeitou o plano inicial, e o Poder Público se constituiu em agente promotor de desigualdades socioespaciais, criação de vazios urbanos e especulação imobiliária.

De um modo geral, o que há são especificações de recuos, taxas e modestos índices de permeabilidade, instrumentos de controle da produção das edificações e loteamentos, que sempre direcionam a produção de espaços livres, que vão surgindo lote a lote, quadra a quadra e loteamento a loteamento, sem que estejam de fato ligados a uma ideia de cidade, de paisagem urbana, que tenha, enfim, formas adequadas às distintas regiões climáticas, geomorfológicas e fitogeográficas do país.

São observados padrões construtivos e formas de ocupação do lote e da quadra bastante similares por todo o Brasil, como no caso de loteamentos fechados, condomínios horizontais e verticais de todos os portes, bem como para a baixa renda, resultado dos programas de moradia popular. Igualmente shopping centers, hipermercados, torres e conjuntos corporativos apresentam configurações muito similares, cidade a cidade. 0 processo de verticalização atual é muito intenso nas principais cidades brasileiras (acima de 500 mil habitantes), produzindo transformação por substituição ou ainda formando novos bairros. É um dos mais importantes elementos de alteração da paisagem urbana.

Nas distintas regiões do país, não se está apenas sob a mesma lógica de produção capitalista do espaço. O Poder Público, nas diversas escalas, quando não também a academia, abdicou de discutir e propor soluções urbanísticas que considerem as inúmeras especificidades regionais e locais. A compreensão dos processos de produção da forma urbana é quesito essencial para a proposta de alternativas para as cidades e metrópoles que considerem as questões ambientais e o viver em público, notadamente nos SEL como elementos norteadores da qualificação urbana.

Faltam projetos de sistema de espaços livres no geral, especificamente espaços destinados ao lazer e à conservação ambiental. Somente o sistema viário costuma ter projetos em longo prazo. É possível afirmar que a ampliação do sistema dos espaços de lazer se dá por políticas e projetos fundamentados em oportunidades, e não em planos estruturais, com uma visão preventiva e de longo prazo, que norteie a ação pública através das décadas. Essa forma de criação com base em oportunidades pode ser observada no cotidiano das cidades brasileiras, como é o caso de São Paulo ou Florianópolis. Poucos são os casos, como de Campo Grande e Rio Branco, em que planos urbanos foram seguidos por gestões sucessivas. 
Em 2019, o conjunto de pesquisas realizadas permitiu afirmar que, a despeito de processos comuns observados nas cidades estudadas das diferentes macrorregiões, seria completamente inadequado formular um manual fechado de recomendações para a qualificação dos SEL das cidades brasileiras. As especificidades e as oportunidades são muito diversas, caso a caso. Não é esperado que uma metrópole interiorana tropical com mais de 21 milhões de habitantes, como São Paulo, possua SEL produzido e apropriado da mesma maneira que uma cidade média, amazônica, de cerca de 300 mil habitantes, como Palmas. Reconhecer a diversidade urbana brasileira e a população envolvida é passo relevante para o estabelecimento de diretrizes propositivas consequentes para seus sistemas de espaços livres e formas urbanas.

Os trabalhos realizados pela Rede QUAPÁ-SEL que relacionam a forma urbana aos processos recentes de ocupação, à legislação e aos agentes produtores do espaço, que apontaram para a existência de especificidades e de oportunidades para ação na transformação de cidades brasileiras, devem ao Prof. Silvio Macedo muito de sua criação e seu impulso. 0 mérito de difundir essa visão sistêmica sobre espaços livres e formas urbanas se entrelaça com o de ter reunido anualmente por volta de 100 pesquisadores, de mais de 20 diferentes universidades.

\section{Referências}

Hough, M. (2004). Cities and nature process: a basis for sustainability. London: Routledge. http://dx.doi.org/10.4324/9780203643471.

Macedo, S. S. (1982). Mutação do espaço urbano: o bairro de Higienópolis (Dissertação de mestrado). Faculdade de Arquitetura e Urbanismo, Universidade de São Paulo, São Paulo.

Macedo, S. S. (1988). Habitação Verticalizada: os espaços livres como elementos de desenho urbano (Tese de doutorado). Faculdade de Arquitetura e Urbanismo, Universidade de São Paulo, São Paulo.

Macedo, S. S. (1993). Paisagem, urbanização e litoral: do Éden à cidade (Tese de livre docência). Faculdade de Arquitetura e Urbanismo, Universidade de São Paulo, São Paulo.

Macedo, S. S. (2015). Quadro do Paisagismo no Brasil: 1783-2000. São Paulo: Edusp.

Macedo, S. S., Queiroga, E. F., Campos, A. C. A., Galender, F. C., \& Custódio, V. (2018). Os sistemas de espaços livres e a constituição da esfera pública contemporânea no Brasil. São Paulo: Edusp.

Macedo, S. S., \& Robba, F. (2002). Praças brasileiras. São Paulo: Edusp.

Macedo, S. S., \& Sakata, F. G. (2002). Parques urbanos no Brasil. São Paulo: Edusp.

Magnoli, M. (1982). Espaços livres e urbanização: uma introdução a aspectos da paisagem metropolitana (Tese de livre docência). Faculdade de Arquitetura e Urbanismo, Universidade de São Paulo, São Paulo.

McHarg, I. (1969). Design with nature. Garden City: American Museum of Nature History.

Morin, E. (2008). O método 1: a natureza da natureza (2a ed.) Porto Alegre: Sulina.

Panerai, P., Depaule, J.-C., \& Demorgon, M. (1999). Analyse Urbaine. Marseille: Parenthèses.

Queiroga, E. (2012). Dimensões públicas do espaço contemporâneo: resistências e transformações de territórios, paisagens e lugares urbanos brasileiros (Tese de livre docência). Faculdade de Arquitetura e Urbanismo, Universidade de São Paulo, São Paulo.

Queiroga, E. F. (2016). Espaços livres, padrões morfológicos e apropriações públicas na metrópole paulistana. Pesquisa em Arquitetura e Construção, 7(3), 178-188. http://dx.doi.org/10.20396/parc.v7i3.8647244.

Santos, M. (1978). Por uma geografia nova: da crítica da geografia a uma geografia crítica (4a ed.) São Paulo: Hucitec.

Santos, M. (1985). Espaço e método. São Paulo: Nobel. 
Santos, M. (1996). A natureza do espaço: técnica e tempo, razão e emoção. São Paulo: Hucitec.

Santos, M. (2005). Da totalidade ao lugar. São Paulo: Edusp.

Silva, A. C. (1986). As categorias como fundamentos do conhecimento geográfico. In M. Santos, \& M. A. Souza (Eds.), Espaço interdisciplinar. São Paulo: Nobel.

Spirn, A. (1995). O jardim de granito: a natureza no desenho da cidade. São Paulo: Edusp.

Editores convidados: Vitor Oliveira (Universidade do Porto, Portugal) e Bruno Zaitter (PUCPR, Brasil)

Recebido: Set. 18, 2019

Aprovado: Mar. 01, 2020 